\title{
PENGARUH JUS DAUN SIRIH (Piper betle Linn) SEBAGAI BAHAN PRECURING DAN LAMA PENYIMPANAN TERHADAP KOMPOSISI KIMIA DAN ANGKA PEROKSIDA DENDENG AYAM PETELUR
}

\section{THE EFFECT OF BETLE LEAF JUICE (Piper betle Linn) AS PRECURING AGENT AND STORAGE TIME ON CHEMICAL COMPOSITION AND PEROXIDE VALUE OF CHICKEN LAYER DENDENG}

\author{
Aloysia Tenny Damayanti Indriastuti ${ }^{1 *}$, Setiyono ${ }^{2}$, dan Yuny Erwanto ${ }^{2}$ \\ ${ }^{1}$ Prodi Peternakan, Fakultas Pertanian, Universitas Musamus, Jl. Kamizaun Mopah Lama, Merauke, 99600 \\ ${ }^{2}$ Fakultas Peternakan, Universitas Gadjah Mada, Jl. Fauna No. 3, Bulaksumur, Yogyakarta, 55281
}

\section{INTISARI}

Penelitian ini bertujuan untuk mengetahui pengaruh jus daun sirih (Piper betle Linn) pada proses precuring dan lama penyimpanan terhadap komposisi kimia dan angka peroksida dendeng ayam petelur. Daging direndam jus daun sirih $(0,5,10$, dan 15\%) kemudian diolah menjadi dendeng. Produk dendeng disimpan pada suhu kamar selama $0,2,4$, 6, dan 8 minggu. Variabel yang diukur meliputi kadar air, kadar protein, kadar lemak, $\mathrm{pH}$, dan angka peroksida. Rancangan penelitian yang digunakan adalah Rancangan Acak Lengkap pola faktorial 4 × 5 dan dilanjutkan dengan uji Tukey. Hasil penelitian menunjukkan bahwa semakin tinggi konsentrasi jus daun sirih berpengaruh nyata $(\mathrm{P}<0,05)$ terhadap kadar air, protein, lemak, dan angka peroksida. Lama simpan hingga minggu kedelapan berpengaruh nyata $(\mathrm{P}<0,05)$ terhadap $\mathrm{pH}$ dan angka peroksida. Interaksi antara konsentrasi jus dan lama simpan terjadi pada angka peroksida. Kesimpulan penelitian ini adalah konsentrasi jus daun sirih dapat digunakan hingga $15 \%$ karena dapat mempertahankan komposisi kimia secara proposional dan menekan angka peroksida sehingga memperpanjang lama penyimpanan dendeng ayam petelur afkir.

(Kata kunci: Daging ayam, Daun sirih, Dendeng, Komposisi kimia, Angka peroksida)

\section{ABSTRACT}

The objective of the experiment was to investigate the effect of betle leaf juice (Piper betle Linn) as precuring agent and storage time on chemical composition and peroxide value of chicken layer dendeng. Chicken meat was dipped in betle leaf juice $(0,5,10$, and 15\%) and than processed into dendeng and stored at room temperature for 0, 2, 4, 6 and 8 weeks, respectively. Variables measured included moisture content, protein, fat, $p H$ and peroxide value. The research design used was Completely Randomized Design 4 × 5 factorial and continued by Tukey test. The results showed that higher concentrations of betle leaf juice significantly effected $(P<0.05)$ on moisture content, protein, fat and peroxide value of chicken dendeng. Storage times up to eight weeks had significant effect $(P<0.05)$ on $p H$ and peroxide value. Interaction between concentrations of juice and storage times was found only on peroxide value. The conclusion of this research was that the betle leaf juice could be applied up to concentration of $15 \%$ because could prevent chemical composition propotionally and reduced peroxide value, hence it could extend the shelf life of dendeng up to eight weeks.

(Key words: Chicken meat, Betle leaf, Dendeng, Chemical composition, Peroxide value)

\section{Pendahuluan}

Daun sirih (Piper betle L.) adalah salah satu jenis tanaman obat (fitofarmaka) yang telah dikenal sebagai bahan pengobatan tradisional maupun sebagai budaya pada upacara adat di sebagian besar penduduk daerah di Indonesia. Pengobatan dengan menggunakan daun sirih secara tradisional ternyata dapat menyembuhkan berbagai penyakit atau paling

\footnotetext{
*Korespondensi (corresponding author):

Telp. +62 8124820704

E-mail: tennydamayanti@yahoo.co.id
}

tidak mengurangi rasa sakit dan menambah kebugaran tubuh (Moelyanto dan Mulyono, 2004).

Daun sirih melalui beberapa penelitian terdahulu terbukti dapat bersifat antifungi, antibakteri bahkan antioksidan, hal ini disebabkan karena di dalam ekstrak daun sirih mengandung minyak atsiri di antaranya adalah senyawa kavikol dan eugenol sehingga dapat dijadikan alternatif bahan pengawet alami daging.

Salah satu bentuk produk olahan daging agar awet dan tahan lama adalah dendeng, dimana pengolahannya melibatkan proses curing dan pengeringan. Daging yang biasanya diolah menjadi 
produk dendeng adalah daging sapi akan tetapi daging ternak lain seperti ayam juga dapat diolah menjadi dendeng. Jariyah dan Susiloningsih (2006) menyatakan bahwa daging ayam broiler yang diolah menjadi dendeng mempunyai rasa yang dapat diterima oleh konsumen seperti dendeng sapi pada umumnya.

Potensi minyak atsiri daun sirih yang mengandung senyawa fenol ini mempunyai sifat antimikrobia dan antioksidan. Penggunaannya dapat menghambat proses ketengikan dan aktifitas mikrobia pada dendeng sehingga produk menjadi lebih tahan lama dan aman untuk dikonsumsi. Hal inilah yang menjadi dasar penelitian penggunaan jus daun sirih sebagai bahan precuring dan pengaruhnya terhadap produk dendeng ayam petelur selama penyimpanan.

\section{Materi dan Metode}

\section{Waktu dan tempat penelitian}

Penelitian ini dilakukan pada bulan Oktober 2010 sampai dengan Februari 2011. Pembuatan jus daun sirih, dendeng dan uji kimia dendeng dilakukan di Laboratorium Pangan Hasil Ternak Fakultas Peternakan UGM dan pengujian angka peroksida dilakukan di Laboratorium Kimia Bahan Pangan Fakultas Teknologi Pertanian Universitas Gadjah Mada, Yogyakarta.

\section{Materi penelitian}

Bahan penelitian. Bahan-bahan penelitian meliputi, sampel bagian keseluruhan otot dada (sternum) tanpa spesifikasi daging dada ayam petelur afkir, jus daun sirih, gula merah, garam $(\mathrm{NaCl})$, sampel dendeng ayam, aquades, alkohol $70 \%$, benzen methanol, larutan $\mathrm{FeSO}_{4}$, larutan $\mathrm{NH}_{4} \mathrm{CNS}$ untuk pengujian angka peroksida.

Alat penelitian. Peralatan yang dipakai pada penelitian ini adalah, lemari es, oven, pisau, gunting, blender, timbangan, alat destruksi, alat destilasi, cawan porselin, waterbath, labu takar, tabung reaksi, penyumbat tabung reaksi, rak, $\mathrm{pH}$ meter, erlemeyer, kertas saring, plastik polietylene, spidol, label, foodscan dan perangkatnya, spectrofotometer, serta alat penunjang lainnya.

\section{Metode penelitian}

Alur penelitian. Sampel penelitian daging bagian dada (sternum) diambil dari pasar tradisional Demangan, Sleman. Pengambilan sampel dilakukan pukul 05.30 WIB dan langsung dibawa ke Laboratorium Pangan Hasil Ternak UGM untuk penyiapan sampel. Daun sirih untuk jus diambil pukul 06.00 WIB, dengan kriteria berwarna hijau tua, diameter 5-15 $\mathrm{cm}$ dan terletak 3-4 daun dari pucuk batang sirih, diblender dan dijadikan jus 50\% dengan cara menimbang daun sirih 1000 gram dan mencampurnya dengan aquadest $1000 \mathrm{ml}$. Jus yang diperoleh disaring, dan filtrat yang diperoleh diencerkan menjadi 5, 10, dan 15\%. Daging ayam yang telah bersih dilakukan precuring dengan jus daun sirih 20 jam kemudian dicuring dengan bumbu-bumbu terdiri dari garam dapur 25 gram, gula 15 gram, bawang putih 20 gram, ketumbar 20 gram, jahe 10 gram dan lengkuas 10 gram untuk 1 kilogram daging (dendeng gurih) selama 5 jam dan dioven pada temperatur $60^{\circ} \mathrm{C}$ hingga kering.

Rancangan penelitian. Produk dendeng yang dihasilkan dengan konsentrasi jus daun sirih 0 , 5,10 , dan $15 \%$ selanjutnya dikemas dalam plastik polietilene dan disimpan dalam suhu ruang dengan lama penyimpanan $0,2,4,6$, dan 8 minggu. Pengamatan untuk masing-masing sampel diulang sebanyak 3 kali.

Variabel pengamatan. Variabel yang diamati adalah kualitas kimia dendeng meliputi kadar air, kadar protein, kadar lemak, derajat keasaman $(\mathrm{pH})$ dan angka peroksida sebagai indikator tingkat menuju ketengikan sedangkan kualitas mikrobiologi menggunakan Total Plate Count (TPC). Pengamatan terhadap kualitas kimia, $\mathrm{pH}$ dan angka peroksida dimulai sejak bahan menjadi produk dendeng hingga masa peyimpanan 8 minggu.

Pengujian kualitas kimia meliputi kadar air, lemak dan protein menggunakan Near-Infrared (NIR) foodscan, angka peroksida dilakukan dengan metode modifikasi Apriyantono et al. (1989) dan Uji derajat keasaman $(\mathrm{pH})$ menggunakan metode Bouton et al. (1971) cit. Soeparno (2005).

Analisis data. Data hasil perhitungan meliputi kadar air, protein, lemak, derajat keasaman (pH) dan angka peroksida dianalisis dengan menggunakan Rancangan Acak Lengkap pola faktorial (4 x 5). Faktor pertama konsentrasi jus daun sirih $(0,5$, 10, dan 15\%) dan faktor kedua lama penyimpanan $(0,2,4,6$, dan 8 minggu) dan perbedaan yang terjadi dilanjutkan uji Tukey's Studentized Range.

\section{Hasil dan Pembahasan}

\section{Komposisi kimia dendeng}

Kadar air. Hasil analisis statistik menunjukkan bahwa konsentrasi jus daun sirih berpengaruh nyata $(\mathrm{P}<0,05)$ terhadap kadar air dendeng sedangkan lama simpan tidak berpengaruh terhadap kadar air (Tabel 1).

Peningkatan kadar air disebabkan perlakuan mengalami dua kali perendaman yaitu precuring jus daun sirih dan curing bumbu dendeng. Suryaningsih (2006) dan Suharyanto (2007) menyatakan bahwa kadar air produk olahan daging dipengaruhi oleh perlakuan saat proses pengolahan seperti perendaman pada saat precuring dan curing. 
Tabel 1. Rerata kadar air dendeng pada berbagai konsentrasi jus daun sirih dan lama penyimpanan (\%) (mean of water content of dendeng at different concentrations of betle leaf juice as precuring and storage times (\%))

\begin{tabular}{|c|c|c|c|c|c|}
\hline \multirow{2}{*}{$\begin{array}{c}\text { Lama simpan (minggu) } \\
\text { (storage time (weeks)) }\end{array}$} & \multicolumn{4}{|c|}{ Konsentrasi jus daun sirih (\%) (betle leaf juice concentrations (\%)) } & \multirow{2}{*}{ Rerata (average) $^{\text {ns }}$} \\
\hline & 0 & 5 & 10 & 15 & \\
\hline 0 & $35,74 \pm 1,46$ & $38,97 \pm 0,29$ & $42,00 \pm 2,25$ & $43,10 \pm 1,93$ & $39,95 \pm 1,48$ \\
\hline 2 & $35,77 \pm 1,55$ & $39,15 \pm 0,35$ & $42,13 \pm 2,16$ & $43,31 \pm 1,85$ & $40,09 \pm 1,48$ \\
\hline 4 & $35,78 \pm 1,45$ & $39,52 \pm 0,48$ & $42,39 \pm 2,06$ & $43,62 \pm 1,84$ & $40,32 \pm 1,46$ \\
\hline 6 & $36,05 \pm 1,26$ & $39,73 \pm 0,36$ & $42,58 \pm 1,99$ & $43,92 \pm 1,89$ & $40,57 \pm 1,38$ \\
\hline 8 & $36,18 \pm 1,35$ & $40,07 \pm 0,40$ & $42,72 \pm 2,02$ & $44,15 \pm 1,94$ & $40,78 \pm 1,43$ \\
\hline Rerata (average) & $35,90 \pm 1,41^{\mathrm{a}}$ & $39,49 \pm 0,37^{b}$ & $42,36 \pm 2,10^{\mathrm{c}}$ & $43,62 \pm 1,89^{\mathrm{c}}$ & \\
\hline
\end{tabular}

Kecenderungan kadar air yang meningkat disebabkan karena penyimpanan dendeng dilakukan pada suhu ruang dan produk walaupun telah dikemas dengan kantong plastik polietilen masih dapat berinteraksi dengan kondisi ruangan penyimpanan dengan menyerap air dari udara sekitarnya.

Kadar protein. Hasil analisis statistik menunjukkan bahwa konsentrasi jus daun sirih berpengaruh nyata $(\mathrm{P}<0,05)$ terhadap kadar protein dendeng (Tabel 2). Lama simpan tidak berpengaruh nyata terhadap kadar protein.

Nilai kadar protein yang menurun dengan meningkatnya konsentrasi jus daun sirih berhubungan erat dengan kadar air produk yang dihasilkan. Sebagaimana diketahui bahwa kadar air pada perlakuan cenderung mengalami peningkatan seiring bertambahnya konsentrasi jus daun sirih sehingga kadar protein yang dihasilkan menurun dan kadar lemak yang dihasilkan meningkat, hal ini sesuai dengan komposisi kimia produk olahan berbahan dasar daging dimana ada keserasian antara kadar air, kadar protein dan kadar lemak secara proposional berbasis bahan kering.

Susilawati (2007) dan Rahmawati et al. (2008) menyatakan bahwa di dalam produk olahan dengan menggunakan panas akan menyebabkan turunnya kadar air dan terjadi peningkatan protein dan lemak berbasis bahan kering sedangkan Riyanto (2006) dan Suharyanto (2007) menyatakan proses pengolahan dan perlakuan suatu produk olahan daging dapat mempengaruhi hasil akhir dari produk tersebut.

Kecenderungan kadar protein yang meningkat selama masa penyimpanan (Tabel 2) diduga karena ada hubungan dengan nilai kadar air dan kadar lemak yang cenderung meningkat namun sangat kecil dan tidak mempengaruhi komposisi kimia proposional hasil produk olahan dendeng ayam tersebut secara keseluruhan.

Kadar lemak. Hasil analisis statistik menunjukkan bahwa konsentrasi jus daun sirih ber- pengaruh nyata $(\mathrm{P}<0,05)$ terhadap kadar lemak dendeng. Kadar lemak meningkat hingga konsentrasi jus $10 \%$ kemudian menurun pada konsentrasi 15\% (Tabel 3). Hasil ini berkaitan erat dengan komposisi kadar protein yang dihasilkan dan akan saling melengkapi secara proposional. Seperti diketahui kadar protein pada berbagai konsentrasi menurun hingga konsentrasi 10\% kemudian meningkat pada konsentrasi $15 \%$ begitu pula sebaliknya dengan kadar lemak yang dihasilkan meningkat hingga konsentrasi 10\% kemudian menurun pada konsentrasi $15 \%$.

Lawrie (2003) dan Soeparno (2011) menyatakan bahwa komposisi kimia daging olahan dengan metode pengeringan, pemanasan dan pemasakan pada suhu tertentu akan menyebabkan kandungan air menurun sedangkan kandungan protein dan lemak meningkat tetapi tetap pada komposisi kimia yang proposional dimana nilai kandungan lemak lebih tinggi akan direfleksikan dengan kandungan protein yang lebih rendah begitu pula sebaliknya.

Kadar lemak yang meningkat selama masa penyimpanan yaitu berturut-turut peningkatan $\pm 0,05 \%$ tidak mempengaruhi komposisi kimia secara keseluruhan karena peningkatannya sangat kecil dan masih tetap pada nilai yang proposional berbasis bahan kering.

Nilai pH. Hasil analisis statistik menunjukkan bahwa konsentrasi jus daun sirih tidak berpengaruh nyata terhadap $\mathrm{pH}$ dendeng (Tabel 4). Nilai $\mathrm{pH}$ dendeng cenderung menurun pada berbagai konsentrasi karena jus daun sirih mempunyai sifat asam yang terdiri dari asam karbosilat dan kandungan senyawa fenol dan turunannya yang juga bersifat asam, selain daging itu sendiri juga mengandung asam diantaranya asam laktat, propionat dan butirat yang apabila mengalami pemanasan akan meningkatkan jumlah konsentrasi sehingga menghasilkan $\mathrm{pH}$ produk dendeng ayam petelur menjadi lebih rendah. 
Tabel 2. Rerata kadar protein dendeng pada berbagai konsentrasi jus daun sirih dan lama penyimpanan (\%) (mean of protein content of dendeng at different concentrations of betle leaf juice and storage times (\%))

\begin{tabular}{|c|c|c|c|c|c|}
\hline \multirow{2}{*}{$\begin{array}{l}\text { Lama simpan (minggu) } \\
\text { (storage time (weeks)) }\end{array}$} & \multicolumn{4}{|c|}{ Konsentrasi jus daun sirih (\%) (betle leaf juice concentrations (\%)) } & \multirow{2}{*}{ Rerata (average) $^{\text {ns }}$} \\
\hline & 0 & 5 & 10 & 15 & \\
\hline 0 & $46,01 \pm 0,85$ & $43,58 \pm 1,27$ & $40,13 \pm 0,84$ & $41,21 \pm 2,67$ & $42,73 \pm 1,41$ \\
\hline 2 & $46,07 \pm 0,79$ & $43,70 \pm 1,29$ & $40,34 \pm 0,70$ & $41,30 \pm 2,65$ & $42,85 \pm 1,36$ \\
\hline 4 & $46,20 \pm 0,71$ & $43,85 \pm 1,24$ & $40,53 \pm 0,75$ & $41,50 \pm 2,59$ & $43,02 \pm 1,32$ \\
\hline 6 & $46,35 \pm 0,91$ & $44,13 \pm 1,16$ & $40,75 \pm 0,83$ & $41,73 \pm 2,69$ & $43,24 \pm 1,40$ \\
\hline 8 & $46,59 \pm 0,02$ & $44,26 \pm 1,18$ & $40,96 \pm 0,77$ & $41,97 \pm 2,85$ & $43,45 \pm 1,21$ \\
\hline Rerata (average) & $46,24 \pm 0,66^{\mathrm{a}}$ & $43,90 \pm 1,23^{b}$ & $40,54 \pm 0,78^{\mathrm{c}}$ & $41,54 \pm 2,69^{\mathrm{c}}$ & \\
\hline
\end{tabular}

Tabel 3. Rerata kadar lemak dendeng pada berbagai konsentrasi jus daun sirih dan lama penyimpanan (\%) (mean of lipid content of dendeng at different concentrations of betle leaf juice and storage times (\%))

\begin{tabular}{|c|c|c|c|c|c|}
\hline \multirow{2}{*}{$\begin{array}{c}\text { Lama simpan (minggu) } \\
\text { (storage time (weeks)) }\end{array}$} & \multicolumn{4}{|c|}{ Konsentrasi jus daun sirih (\%) (betle leaf juice concentrations (\%)) } & \multirow{2}{*}{${\text { Rerata }(\text { average })^{\mathrm{ns}}}$} \\
\hline & 0 & 5 & 10 & 15 & \\
\hline 0 & $6,77 \pm 0,28$ & $7,71 \pm 0,70$ & $8,78 \pm 0,20$ & $8,31 \pm 1,22$ & $7,89 \pm 0,60$ \\
\hline 2 & $6,78 \pm 0,28$ & $7,76 \pm 0,74$ & $8,80 \pm 0,21$ & $8,36 \pm 1,19$ & $7,92 \pm 0,61$ \\
\hline 4 & $6,79 \pm 0,29$ & $7,85 \pm 0,81$ & $8,92 \pm 0,14$ & $8,43 \pm 1,24$ & $7,99 \pm 0,62$ \\
\hline 6 & $6,81 \pm 0,30$ & $7,89 \pm 0,77$ & $8,98 \pm 0,10$ & $8,50 \pm 1,22$ & $8,05 \pm 0,60$ \\
\hline 8 & $6,86 \pm 0,28$ & $7,97 \pm 0,69$ & $9,03 \pm 0,10$ & $8,58 \pm 1,21$ & $8,11 \pm 0,82$ \\
\hline Rerata (average) & $6,80 \pm 0,29^{\mathrm{a}}$ & $7,84 \pm 0,74^{b}$ & $8,90 \pm 0,15^{\mathrm{bc}}$ & $8,44 \pm 1,22^{\mathrm{c}}$ & \\
\hline
\end{tabular}

Sari dan Isadiartuti (2006) mengemukakan bahwa kandungan ekstrak daun sirih bersifat asam karena mengandung asam karbosilat yang meliputi asam formiat, asetat dan butirat sehingga dengan semakin meningkatnya konsentrasi maka akan meningkatkan sifat asam dari bahan yang diberikan.

Hasil analisis statistik menunjukkan bahwa lama penyimpanan berpengaruh nyata $(\mathrm{P}<0,05)$ terhadap $\mathrm{pH}$ dendeng. Makin lama waktu penyimpanan makin tinggi pula nilai $\mathrm{pH}$ disebabkan oleh sebagian senyawa fenolik dan asam-asam lemak pada produk menguap dan jumlahnya menjadi berkurang dan menyebabkan $\mathrm{pH}$ dendeng ayam meningkat selama masa penyimpanan.

Suradi (2005) dan Arizona (2010) mengemukakan bahwa selama masa penyimpanan, bakteri dapat menyebabkan dekomposisi senyawa kimia pada daging ataupun produk olahannya, khususnya protein akan dipecah menjadi senyawa yang lebih sederhana dan berlanjut hingga menghasilkan senyawa seperti $\mathrm{NH}_{3}$ dan $\mathrm{H}_{2} \mathrm{~S}$.

Hasil penelitian ini menunjukkan bahwa komposisi kimia tidak mengalami perubahan secara signifikan selama penyimpanan 8 minggu, sehingga kenaikan $\mathrm{pH}$ yang terjadi pada produk dendeng bukan disebabkan oleh dekomposisi senyawa kimia melainkan oleh menguapnya sebagian senyawa fenolik dan asam-asam lemak dari produk dendeng tersebut.

Angka peroksida. Hasil analisis statistik menunjukkan bahwa perlakuan konsentrasi jus daun sirih dan lama penyimpanan berpengaruh sangat nyata $(\mathrm{P}<0,05)$ terhadap angka peroksida. Angka peroksida menurun seiring dengan peningkatan konsentrasi jus daun sirih dan meningkat seiring dengan lama waktu penyimpanan. Hasil yang disajikan pada Tabel 5 membuktikan bahwa zat anti oksidan seperti fenol dan eugenol yang terdapat dalam jus daun sirih berperan memperkecil proses oksidasi. Penghambatan proses oksidasi asam lemak tak jenuh pada produk dendeng ayam bertujuan agar produk lebih tahan dan tidak cepat menjadi tengik pada masa penyimpanan.

Menurut Legowo et al. (2002); Jariyah dan Susiloningsih (2006) menyatakan bahwa fenol dan eugenol merupakan antioksidan alami bertipe fenolik yaitu bahan yang berperanan penting sebagai akseptor radikal bebas yang mampu membentuk senyawa stabil dengan tidak meneruskan oksidasi gliserid lebih lanjut atau dengan kata lain mempunyai aktifitas menghambat oksidasi asam lemak tak jenuh. 
Tabel 4. Rerata $\mathrm{pH}$ dendeng pada berbagai konsentrasi jus daun sirih dan lama penyimpanan (mean of $\mathrm{pH}$ dendeng at different concentrations of betle leaf juice and storage times)

\begin{tabular}{|c|c|c|c|c|c|}
\hline \multirow{2}{*}{$\begin{array}{c}\text { Lama simpan (minggu) } \\
\text { (storage time (weeks)) }\end{array}$} & \multicolumn{4}{|c|}{ Konsentrasi jus daun sirih (\%) (betle leaf juice concentrations (\%)) } & \multirow{2}{*}{ Rerata (average) $^{\text {ns }}$} \\
\hline & 0 & 5 & 10 & 15 & \\
\hline 0 & $5,85 \pm 0,05$ & $5,81 \pm 0,08$ & $5,76 \pm 0,09$ & $5,74 \pm 0,08$ & $5,79 \pm 0,08^{\mathrm{a}}$ \\
\hline 2 & $5,87 \pm 0,08$ & $5,84 \pm 0,13$ & $5,78 \pm 0,19$ & $5,77 \pm 0,22$ & $5,81 \pm 0,16^{\mathrm{a}}$ \\
\hline 4 & $5,91 \pm 0,09$ & $5,87 \pm 0,09$ & $5,81 \pm 0,28$ & $5,80 \pm 0,26$ & $5,85 \pm 0,18^{\mathrm{ab}}$ \\
\hline 6 & $6,03 \pm 0,02$ & $5,99 \pm 0,04$ & $5,98 \pm 0,05$ & $5,96 \pm 0,05$ & $5,99 \pm 0,04^{\mathrm{b}}$ \\
\hline 8 & $6,39 \pm 0,14$ & $6,31 \pm 0,30$ & $6,22 \pm 0,15$ & $6,12 \pm 0,05$ & $6,26 \pm 0,16^{\mathrm{c}}$ \\
\hline Rerata $\left(\right.$ average) $^{\mathrm{ns}}$ & $6,00 \pm 0,08$ & $5,96 \pm 0,13$ & $5,91 \pm 0,15$ & $5,88 \pm 0,13$ & \\
\hline
\end{tabular}

Tabel 5. Rerata angka peroksida dendeng pada berbagai konsentrasi jus daun sirih dan lama penyimpanan (meq $/ \mathrm{kg}$ ) (mean of peroxide value of dendeng at different concentrations of betle leaf juice and storage times (meq $/ \mathrm{kg})$ )

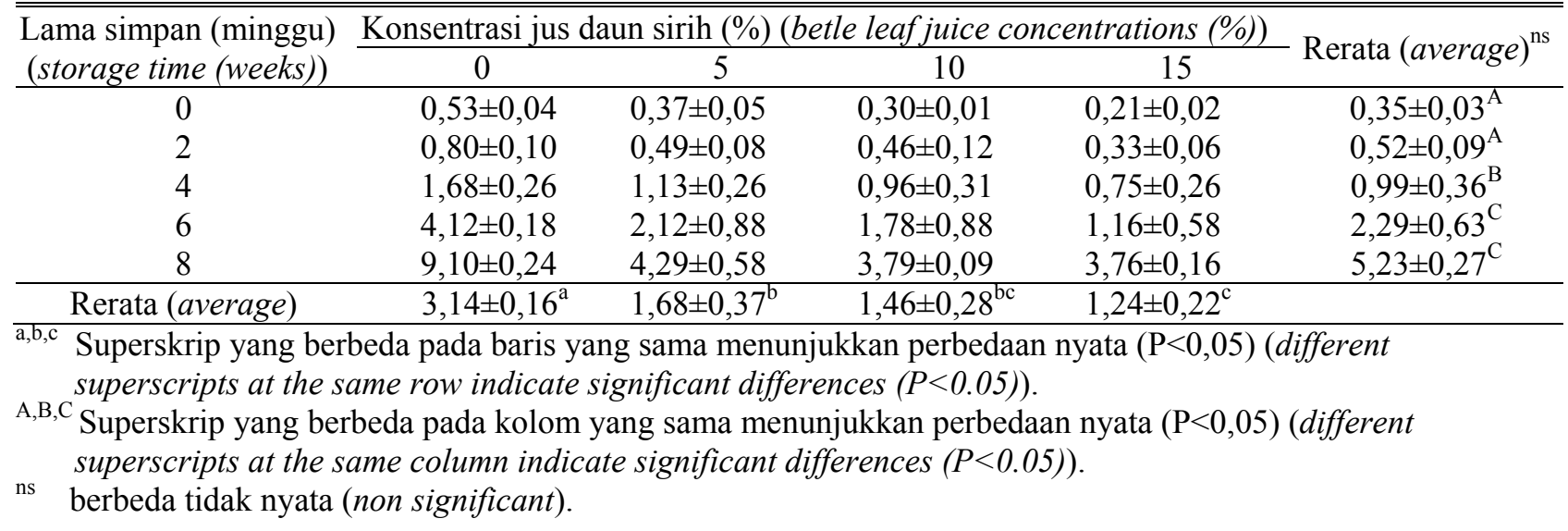

\section{Kesimpulan dan Saran}

\section{Kesimpulan}

Berdasarkan hasil penelitian dapat disimpulkan bahwa 1) Konsentrasi jus daun sirih pada proses precuring dapat digunakan hingga 15\% karena dapat mempertahankan komposisi kimia proposional dan menekan angka peroksida, 2) Lama penyimpanan dendeng ayam petelur afkir hingga minggu kedelapan pada berbagai konsentrasi masih mempunyai komposisi kimia yang baik dan angka peroksida relatif kecil.

\section{Saran}

Penelitian lanjut dapat dilakukan untuk mengetahui batas penyimpanan maksimum pada produk dendeng yang dihasilkan.

\section{Daftar Pustaka}

Apriyantono, A., D. Fardiaz, N.L. Pusputasari, Sedarnawati, dan S. Budiyanto. 1989. Analisis Pangan. Pusat Antar Universitas. Institut Pertanian Bogor. Bogor.
Arizona, R. 2010. Pengaruh asap cair tempurung kenari dan lama penyimpanan terhadap kualitas kimia, fisik dan mikrobiologis daging. Tesis Program Pascasarjana. Fakultas Peternakan Universitas Gadjah Mada Yogyakarta.

Jariyah dan E.K.B. Susiloningsih. 2006. Pengaruh perendaman daging ayam dalam jus daun sirih terhadap daya simpan dendeng ayam. Jurnal Protein 13(2): 154-160.

Lawrie, R.A. 2003. Ilmu Daging. Edisi Kelima. Terjemahan Aminuddin. Penerbit Universitas Indonesia, Jakarta.

Legowo, M.A., R. Soepardi, Miranda,Y. Anisa, dan Rohidayah. 2002. Pengaruh perendaman daging pra kyuring dalam jus daun sirih terhadap ketengikan dan sifat organoleptik dendeng sapi selama penyimpanan. Jurnal Teknologi dan Industri Pangan. 13(1): 64-69.

Moelyanto dan Mulyono. 2004. Khasiat dan Manfaat Daun Sirih Obat Mujarab dari Masa ke Masa. Edisi I. Agromedia Pustaka, Jakarta. pp 1-69. 
Rahmawati, H., I.K. Khotimah, dan J. Achmad. 2008. Pengolahan ikan kering Tenggiri (Scomberomorus commersonni) berupa "Stik" dengan variasi kadar garam dan lama penggaraman. Seminar Nasional Tahunan V. Hasil Penelitian Perikanan dan Kelautan. Semnaskan_UGM/Pasca Panen/ PP-16.

Riyanto, I. 2006. Analisis kadar, daya cerna dan karakteristik protein daging ayam kampung dan olahannya. Skripsi. Program Studi Teknologi Hasil Ternak. Fakultas Peternakan Institut Pertanian Bogor.

Sari, R. dan D. Isadiartuti. 2006. Studi efektifitas sediaan gel antiseptik tangan ekstrak daun sirih (Piper Betle L.). Majalah Farmasi Indonesia, 17(4): 163-169.

Soeparno. 2005. Ilmu Teknologi Daging. Cetakan IV, Gadjah Mada University Press, Yogyakarta

Soeparno. 2011. Ilmu Nutrisi Gizi Daging. Cetakan I, Gadjah Mada University Press, Yogyakarta.
Suharyanto. 2007. Karakteristik dendeng daging giling pada pencucian (leaching) dan jenis daging yang berbeda. Tesis. Program Pascasarjana, Institut Pertanian Bogor.

Suradi, K. 2005. Aplikasi Model Arrhenius untuk Pendugaan Penurunan Masa Simpan Daging Sapi Pada Penyimpanan Suhu Ruang dan Refrigerasi Berdasarkan nilai TVB dan $\mathrm{pH}$. Fakultas Peternakan. Universitas Padjadjaran.

Suryaningsih, L. 2006. Pengaruh jenis daging, penambahan antidenaturan dan natrium trifolifosfat pada nikumi terhadap karakteristik daging olahan. Disertasi Sekolah Pascasarjana. Institut Pertanian Bogor.

Susilawati, I. 2007. Kajian metode pengasapan dalam pengolahan dendeng batokok produk khas Sumatera Barat. Tesis Pascasarjana Teknologi Pasca Panen. Institut Pertanian Bogor. 